\title{
A Retrospective Study on the Hematological Parameters of Diabetic and Non Diabetic Individuals
}

\author{
N.E.Kaviya ${ }^{1}$, Dr. M. P. Brundha ${ }^{* 2}$ and Dr. Preejitha. V.B ${ }^{3}$ \\ ${ }^{1}$ Graduate, Department of Pathology Saveetha Dental College, Saveetha Institute of Medical \\ and Technical Sciences, Saveetha University, India \\ ${ }^{2}$ Associate professor, Department of Pathology Saveetha Dental College, Saveetha \\ Institute of Medical and Technical Sciences, Saveetha University, India \\ ${ }^{3}$ Tutor Department of Pathology Saveetha Dental College, Saveetha Institute \\ of Medical and Technical Sciences Saveetha University. India
}

\section{ABSTRACT}

Diabetes is seen to be a common endocrine disorder that is also associated with cardiac disease. Diabetes is also called a metabolic disorder associated with increased risk of vascular disease and hyperglycemia. One of the classical inflammatory marker associated with diabetes and cardiovascular disease is the elevation in the white blood cell count. This study aimed to find out the difference in the hematological parameters of the diabetic and non diabetic individual. The hematological parameter includes WBC(White blood cells), PCV(Packed cell volume), MCV(Mean corpuscular volume), and Platelet count. The complete blood count values of a sample of 42 patients was collected from the record, that consisted of 21 diabetic and 21 non diabetic patients. The data was collected from the laboratory and was analysed and then statistical analysis was given.The results showed that the hematological parameters showed the increase in the WBC and platelet count in diabetic patients than the non diabetic patients. We also found that there is no significant difference in the Packed cell volume and Mean corpuscular volume of the diabetic and non diabetic patients.

KEY WORDS: DIABETIC, NON DIABETIC, HEMATOLOGICAL,BLOOD, REPORTS..

\section{INTRODUCTION}

Retrospective study is a comparative study between 2 group individuals in this study the groups are the diabetic and non diabetic. Cardiac disease is caused by diabetes in some cases (Nanda et al., 2009). The primary cause for diabetes is cardiac disease. One main component of diabetes is inflammation (Nada, 2015). Diabetes is an endocrine health disorder which is predominantly seen in

\section{ARTICLE INFORMATION}

${ }^{*}$ Corresponding Author: brundha.sdc@saveetha.com Received 10th August 2020 Accepted after revision 25th Sep 2020 Print ISSN: 0974-6455 Online ISSN: 2321-4007 CODEN: BBRCBA

Thomson Reuters ISI Web of Science Clarivate Analytics USA and Crossref Indexed Journal

\section{Clarivate
Analytics}

NAAS Journal Score 2020 (4.31) SJIF: 2020 (7.728)

A Society of Science and Nature Publication,

Bhopal India 2020. All rights reserved.

Online Contents Available at: http//www.bbrc.in/

Doi: http://dx.doi.org/10.21786/bbrc/13.8/108 the individuals. Carbohydrate, fat and protein are produced from the living cells of plants and animals. Decreased production of insulin secretion causes changes in the metabolism of these substances (Alam et al., 2015). Blood is defined as a connective tissue with cellular elements suspended in plasma. Glycemic control is the prevention for the development of diabetic complication (Milosevic and Panin, 2019). Diabetes is a non communicable disease. The decrease in the hemoglobin concentration of the blood is anemia. The diabetic capital of the world is India. Mostly patients with diabetes and renal insufficiency are anemic (S., Srinivasa and K., 2017). Diabetes and Hyperglycemia play an important role in cardiovascular diseases. Hematological parameters include White blood cells (WBC), mean platelet volume (MPV), platelet to lymphocyte ratio (PLR) and neutrophil

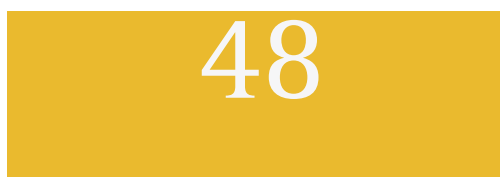


to lymphocyte ratio (NLR). Increase in the White blood cell count gives an inflammatory marker associated with Cardiac diseases (Demirtas et al., 2015).

Routinely measured parameters are White blood cells count and hematocrit level was associated with insulin resistance. Blood glucose was analyzed using a hexokinase method ( $\mathrm{M}$ and Christa M, 2014). According to the Epidemiology pattern several factors play an important role in the distribution of Type 1 diabetesgeographic, cultural, demographic, vitamin D exposure, obesity and environmental pollutants (Iz and Isaac IZ, 2012). Diabetes Mellitus are classified under 2 categoriesType 1 and Type 2 diabetes. Type 2 diabetes patients have increased risk of cardiovascular diseases. Diabetes when poorly treated causes various complications like retinopathy, nephropathy and oxidative stress that causes damage to the tissue and cell (Antwi-Baffour et al., 2018).

Table 1. Shows the WBC value of diabetic and non diabetic individuals, mean value of diabetic patients was 8115 cells/ mm3 and non diabetic patients was 6210 cells/mm3.

\begin{tabular}{|c|c|c|c|c|c|}
\hline \multicolumn{6}{|c|}{ Group Statistics } \\
\hline & VAR00001 & $N$ & Mean & Std. Deviation & $\begin{array}{c}\text { Std. Error } \\
\text { Mean }\end{array}$ \\
\hline \multirow[t]{2}{*}{ VAR00002 } & diabetic & 21 & 8115.0476 & 2811.96448 & 613.62096 \\
\hline & non diabetic & 21 & 6210.5714 & 2184.90340 & 476.78501 \\
\hline
\end{tabular}

Diabetes mellitus patients are monitored by laboratory tests by finding the glycated proteins, insulin, urinary proteins, fructosamine, glucose in urine, C-peptide and kidney function (Milosevic and Panin, 2019). During pregnancy women develop high blood sugar levels and this condition is called Gestational diabetes. Mothers with gestational diabetes with poorly treated causes risk like low blood sugar and jaundice in born babies. Diabetes complication can cause morbidity and mortality (Hope and Ifeanyi, 2019). The changes in the hematological parameters are seen in patients with anemia. (Shukla, 2016). This study was done to compare the hematological parameters among diabetic and non diabetic patients.

\section{MATERIAL AND METHODS}

Sample collection: From the laboratory digital record system, 21 were diabetic individuals and 21 non diabetic individuals with a total of 42 patients were selected and their hematological parameters were noted down. This study was done in Saveetha dental college, clinical laboratory in the month of November 2019. This study was commenced after the approval by the institutional ethical committee, Saveetha Institution of Medical and Technical Science.

Sampling Method: Sampling method followed in our study was Random sampling method.

Inclusion Criteria: Random blood sugar level of more than $200 \mathrm{mg} / \mathrm{dl}$ was considered for diabetic individuals and less than $200 \mathrm{mg} / \mathrm{dl}$ was considered for non diabetic individuals. Age and sex were not considered.

Table 2. Shows the independent T test value of the comparison of the mean values of WBC count in diabetic and non diabetic patients. The WBC count of the diabetic patients was higher than the non diabetic patients of our study and the difference was also statistically significant. The $P$ value of the comparative data was $[\mathrm{P}=0.019(<0.05)]$.

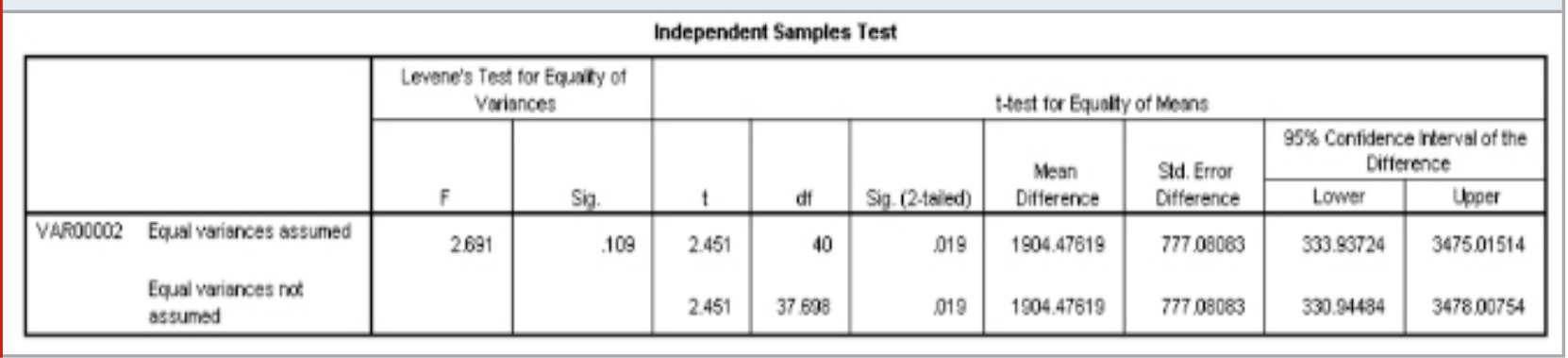

Table 3. Shows the PCV value of diabetic and non diabetic individuals, mean value of diabetic patients was $38 \%$ and non diabetic patients was $36 \%$.

\section{Group Statistics}

\begin{tabular}{|ll|r|r|r|r|}
\hline & VAR00001 & $\mathrm{N}$ & Mean & Std. Deviation & Std. Error Mear \\
\hline VAR00003 & diabetic & 21 & 38.1429 & 6.10152 & 1.33146 \\
& non diabetic & 21 & 36.7619 & 1.86828 & 40769 \\
\hline
\end{tabular}


Exclusion Criteria: Pre-diabetic and hypertensive diabetic individuals were excluded.

\section{RESULTS AND DISCUSSION}

The tables below comparatively show that, higher value of WBC, PCV, MCV and platelets value in diabetic patients than non diabetic patients. It is associated with predicts the development of type 2 diabetes and sensitivity of insulin. Chronic low grade inflammation may be involved in pathogenesis of insulin resistance type 2 diabetes. People with diabetes particularly type 2 diabetes exhibit platelet reactivity. Hyperglycemia contributes to greater platelet reactivity through direct effect and by promoting glycation of platelet. Inflammation promotes platelet activation. Table 1 and 2 shows the comparative mean and independent $t$ test values of the WBC count in diabatic and non diabetic patients. Table 3 and 4 shows the comparative mean and independent t test values of the PCV in diabatic and non diabetic patients. Table 5 and 6 shows the comparative mean and independent $t$ test values of the MCV in diabatic and non diabetic patients. Table 7 and 8 shows the comparative mean and independent $t$ test values of the platelet count in diabatic and non diabetic patients.

Table 4. Shows the independent T test value of the comparison of the mean values of PCV in diabetic and non diabetic patients. The PCV of the diabetic patients was higher than the non diabetic patients of our study. However, the difference was not statistically significant. $[\mathrm{P}=0.327(>0.05)]$.

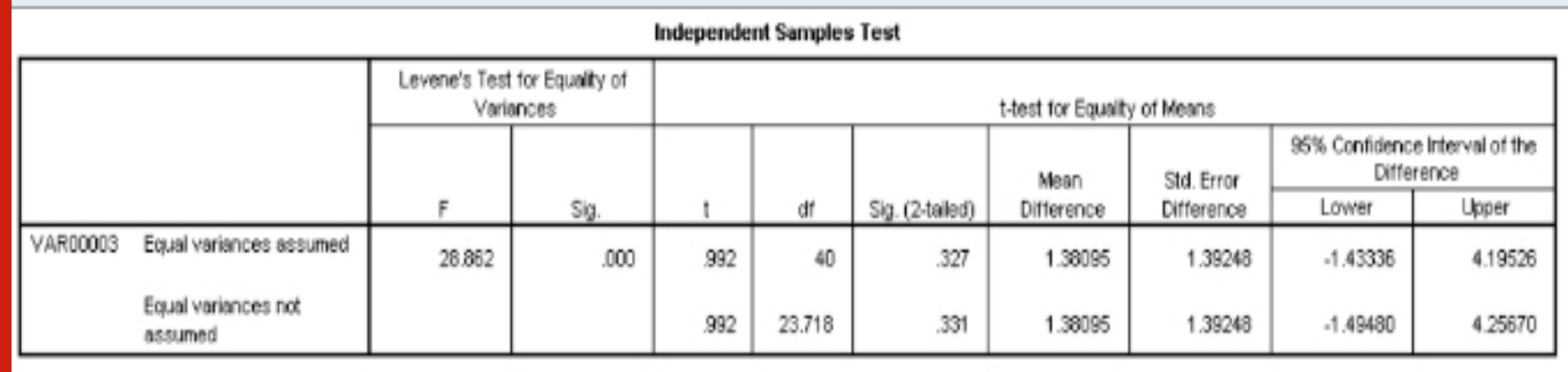

Table 5. Shows the MCV value of diabetic and non diabetic individuals, mean value of diabetic patients was $85 \mathrm{fl}$ and non diabetic patients was $84 \mathrm{fl}$.

\section{Group Statistics}

\begin{tabular}{|ll|r|r|r|r|}
\hline & VAR00001 & N & Mean & Std. Deviation & Std. Error Mear \\
\hline VAR00004 & diabetic & 21 & 85.5238 & 4.28508 & .93508 \\
& non diabetic & 21 & 84.8571 & 3.46822 & .75683 \\
\hline
\end{tabular}

Table 6. Shows the independent T test value of the comparison of the mean values of MCV in diabetic and non diabetic patients. The MCV count of the diabetic patients was higher than the non diabetic patients of our study and the difference was also statistically significant.The $P$ value of the comparative data was $[P=0.583(>0.05)] .4 .85 \mathrm{~m}$

\begin{tabular}{|c|c|c|c|c|c|c|c|c|c|c|}
\hline \multicolumn{11}{|c|}{ Independent Samples Test } \\
\hline & & \multicolumn{2}{|c|}{$\begin{array}{l}\text { Levenes Test for Equalty of } \\
\text { Variances }\end{array}$} & \multicolumn{7}{|c|}{ thest for Equalty of lieans } \\
\hline & & \multirow[b]{2}{*}{$\mathrm{F}$} & \multirow[b]{2}{*}{$9 g}$. & \multirow[b]{2}{*}{$t$} & \multirow[b]{2}{*}{ df } & \multirow[b]{2}{*}{ Sig (2-tailed) } & \multirow{2}{*}{$\begin{array}{l}\text { Mean } \\
\text { Ditterence }\end{array}$} & \multirow{2}{*}{$\begin{array}{l}\text { Std Error } \\
\text { Ditterenoe }\end{array}$} & \multicolumn{2}{|c|}{$\begin{array}{c}95 \% \text { Confidence irterval of the } \\
\text { Ditterence }\end{array}$} \\
\hline & & & & & & & & & Lower & Upper \\
\hline VAR00004 & Equal ysriances assured & 1.125 & .295 & 554 & 40 & .583 & .66667 & 1.20296 & -1.76465 & 3.09796 \\
\hline & $\begin{array}{l}\text { Equal variances not } \\
\text { assumed }\end{array}$ & & & .554 & 38,335 & .583 & .66667 & 1.20298 & .1 .76794 & 3.10120 \\
\hline
\end{tabular}

Cardiovascular complications are closely related to increase in platelet activation and aggregation. Platelet sizes are analyzed and the reactivity was seen (Varol et al., 2010). Insulin acts as a co factor of erythropoiesis (Ellinger et al., 2006). WBC plays an important role in the inflammatory response when the WBC is increased. Pre-diabetic and diabetic has increased in the WBC count. DM status has correlation with biomedical parameters (Worachartcheewan et al., 2013). Several studies show association with insulin resistance (Hanley 
et al., 2009). Insulin is the main substance which helps in the decrease and control of diabetes. According to the article the diabetes individual had a lower amount of hemoglobin, RBC count and HCT. These similar lower concentrations were seen in the type 2 diabetes
(Farooqui, Afsar and Afroze, 2019). Patients with type 2 diabetes had less hemoglobin content. One of the causes for the cardiovascular disease is low hemoglobin concentration.

Table 7. Shows the Platelet count of diabetic and non diabetic individuals, mean value of diabetic individuals was 259307 per microliter and non diabetic individuals was 321220 per microliter.

\section{Group Statistics}

\begin{tabular}{|ll|r|c|c|c|}
\hline & VAR00001 & N & Mean & Std. Deviation & Std. Error Mear \\
\hline VAR00007 & diabetic & 21 & 259307.6190 & 79727.86219 & 17398.04588 \\
& non diabetic & 21 & 321220.0000 & 95257.01911 & 20786.78574 \\
\hline
\end{tabular}

Table 8. Shows the independent $\mathrm{T}$ test value of the comparison of the mean values of platelet count in diabetic and non diabetic patients. The platelet count of the diabetic patients was higher than the non diabetic patients of our study and the difference was also statistically significant. The $\mathrm{P}$ value of the comparative data was $[\mathrm{P}=0.028(<0.05)]$.

\begin{tabular}{|c|c|c|c|c|c|c|c|c|c|c|}
\hline \multicolumn{11}{|c|}{ Independent Samples Test } \\
\hline & & \multicolumn{2}{|c|}{$\begin{array}{c}\text { Levene's Test for Equalty of } \\
\text { Variances }\end{array}$} & \multicolumn{7}{|c|}{ I-test for Equality of Means } \\
\hline & & \multirow[b]{2}{*}{$\mathrm{F}$} & \multirow[b]{2}{*}{$\mathrm{sig}$. } & \multirow[b]{2}{*}{$t$} & \multirow[b]{2}{*}{$d t$} & \multirow[b]{2}{*}{ Sig. (2taled) } & \multirow{2}{*}{$\begin{array}{c}\text { Mean } \\
\text { Ditference }\end{array}$} & \multirow{2}{*}{$\begin{array}{l}\text { Std. Eror } \\
\text { Difference }\end{array}$} & \multicolumn{2}{|c|}{$\begin{array}{l}95 \% \text { Confidence Interval of the } \\
\text { Difference }\end{array}$} \\
\hline & & & & & & & & & Lower & Upper \\
\hline VAR00007 & $\begin{array}{l}\text { Equal variances assumed } \\
\text { Equal variances not } \\
\text { assumed }\end{array}$ & 2.656 & .111 & $\begin{array}{l}.2284 \\
.2284\end{array}$ & $\begin{array}{r}40 \\
38.797\end{array}$ & $\begin{array}{l}.028 \\
.028\end{array}$ & $\begin{array}{l}.61912 .38095 \\
.61912 .38095\end{array}$ & $\begin{array}{l}27106.87112 \\
27106.87112\end{array}$ & $\begin{array}{l}.116697 .411 \\
.116750 .386\end{array}$ & $\begin{array}{l}.7127 .35083 \\
.7074 .37599\end{array}$ \\
\hline
\end{tabular}

Diabetic nephropathy leads to cardiovascular disease (Salhen, Al Salhen and Mahmoud, 2017). In diabetes microvascular complications are high. The PLCR, PCT, PC and MPV were high in the diabetes individual when compared with the non diabetic individuals (Agarwal et al., 2018). The insulin resistance syndrome can be caused by elevation in the erythrocyte criteria. Changes in the glucose of the body even causes liver damage (Kamil, 2015). The hematological parameters are not associated with BMI and obesity. In the non obese people the hemoglobin, hematocrit and high RBC helps in identifying insulin resistance (Barazzoni et al., 2014). In the diabetic individuals the WBC level was high. Diabetes mellitus shows an increased level of platelets which are activated, young or large circulating in the blood. (Khudhur and Al-Ani, 2019). When the WBC level in the blood is elevated it is closely related to Multiple sclerosis (Vivek et al., 2018).

The oxygen carrying capacity can be predicted by using packed cell volume (Biadgo et al., 2016). Glucose lowers the amount of hemoglobin content in the blood (Varim et al., no date). According to the discussion found with the other articles it is clear that the hematological parameters of the diabetic individuals are seen to be high or more when compared to the non diabetic individuals. Limitations of our study include small sample size,patients with anemia and other disorders were not included in the study. future studies may rectify these limitations.

\section{CONCLUSION}

Within the limitations of our study, the hematological parameters showed the increase in the WBC and platelet count in diabetic patients than the non diabetic patients. We also found that there is no significant difference in the Packed cell volume and Mean corpuscular volume of the diabetic and non diabetic patients.

\section{ACKNOWLEDGMENTS}

The authors are thankful to Saveetha Dental College for providing reports for the research work.

Conflict of Interest: None to declare

\section{REFERENCES}

Agarwal, C. et al. (2018) 'Platelet parameters: Can they serve as biomarkers of glycemic control or development of complications in evaluation of type 2 diabetes mellitus?', Iraqi Journal of Hematology, p. 72. doi: 10.4103/ijh.ijh_8_18.

Alam, M. J. et al. (2015) 'a Comparative Analysis Of Biochemical And Hematological Parameters In Diabetic 
And Non-diabetic Adults', An International Journal (AMS), 2(1). Available at: https://airccse.com/ams/ papers/2115ams01.pdf.

Antwi-Baffour, S. et al. (2018) 'Haematological parameters and lipid profile abnormalities among patients with Type-2 diabetes mellitus in Ghana', Lipids in health and disease, 17(1), p. 283. doi: 10.1186/s12944018-0926-y.

Barazzoni, R. et al. (2014) 'The association between hematological parameters and insulin resistance is modified by body mass index - results from the NorthEast Italy MoMa population study', PloS one, 9(7), p. e101590. doi: 10.1371/journal.pone.0101590.

Biadgo, B. et al. (2016) 'Hematological indices and their correlation with fasting blood glucose level and anthropometric measurements in type 2 diabetes mellitus patients in Gondar, Northwest Ethiopia', Diabetes, metabolic syndrome and obesity: targets and therapy, 9, pp. 91-99. doi: 10.2147/DMSO.S97563.

Demirtas, L. et al. (2015) 'Association of hematological indices with diabetes, impaired glucose regulation and microvascular complications of diabetes', International journal of clinical and experimental medicine, 8(7), pp. 11420-11427. Available at: https://www.ncbi.nlm.nih. gov/pubmed/26379958.

Ellinger, V. C. M. et al. (2006) 'Relation between insulin resistance and hematological parameters in a Brazilian sample', Arquivos Brasileiros de Endocrinologia Et Metabologia, pp. 114-117. doi: 10.1590/s000427302006000100016.

Farooqui, R., Afsar, N. and Afroze, I. A. (2019) 'Role and Significance of Hematological parameters in Diabetes Mellitus', Annals of Pathology and Laboratory Medicine, 6(3), pp. A158-162. doi: 10.21276/apalm.2355.

Hanley, A. J. G. et al. (2009) 'Association of Hematological Parameters with Insulin Resistance and $\beta$-Cell Dysfunction in Nondiabetic Subjects', The Journal of Clinical Endocrinology \& Metabolism, pp. 3824-3832. doi: 10.1210/jc.2009-0719.

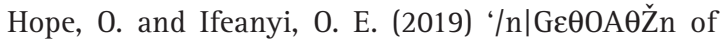
Some Haematological Parameters in Pregnant Women with 'GeIAӨŽnAu Diabetes at Federal Medical Center, Owerri, Imo State, Nigeria', Annals of Clinical and Laboratory Research, 7(2). Available at: https://www. aclr.com.es/clinical-research/investigation-of-somehaematological-parameters-in-pregnant-women-withgestational-diabetes-at-federal-medical-center-owerriimo-s.pdf.

Iz, E. O. I. and Isaac IZ, E. O. (2012) 'Some Haematological Parameters in Patients with Type-1 Diabetes in Sokoto, North Western Nigeria', Journal of Blood \& Lymph. doi: 10.4172/2165-7831.1000110.

Kamil, Z. H. (2015) 'A Comparative Study of Hematological,Renal And Liver Function Criteria in Type I and Type II Diabetes Mellitus', Medical Journal of Babylon. Babylon University, 12(3), pp. 763-773. Available at: http://www.iasj. net? func $=$ article\&taId $=106147$ (Accessed: 30 June 2020).

Khudhur, K. and Al-Ani, M. (2019) 'Hematological parameters in children with type-1 diabetes'. unknown, 16(3), p. 184. doi: 10.4103/MJBL.MJBL_24_19.

Milosevic, D. and Panin, V. L. (2019) 'Relationship Between Hematological Parameters and Glycemic Control in Type 2 Diabetes Mellitus Patients', Journal of Medicine and Biochemistry, 38(2), pp. 164-171. doi: 10.2478/jomb-2018-0021.

M, W. R. C. and Christa M, W. R. (2014) 'Hematological Parameters and Prediabetes and Diabetes in Adults from the General Population: A Cross-Sectional Study', Journal of Diabetes \& Metabolism. doi: 10.4172/21556156.1000335.

Nada, A. M. (2015) 'Red cell distribution width in type 2 diabetic patients', Diabetes, metabolic syndrome and obesity: targets and therapy, 8, pp. 525-533. doi: 10.2147/DMSO.S85318.

Nanda, N. et al. (2009) 'Myocardial infarction in nondiabetic and prediabetic population: a retrospective analysis', Indian journal of physiology and pharmacology, 53(4), pp. 334-340. Available at: https://www.ncbi.nlm. nih.gov/pubmed/20509325.

Salhen, K. A., Al Salhen, K. and Mahmoud, A. (2017) 'Hematological profile of patients with type 2 diabetic mellitus in El-Beida, Libya', Ibnosina Journal of Medicine and Biomedical Sciences, p. 76. doi: 10.4103/1947-489x.210115.

S., H. K., Srinivasa, S. V. and K., P. (2017) 'Haematological profile of diabetes and non-diabetes patients in rural tertiary centre', International Journal of Advances in Medicine, p. 1271. doi: 10.18203/2349-3933. ijam20174111.

Shukla, D. K. (2016) 'Study of hematological indices in patients with diabetes mellitus and hypertensive diabetes mellitus', International Journal of Medicine Research, 1(4), pp. 28-31.

Varim, C. et al. (no date) 'Effects of Glucose Control on Hematological Indices in Patients with Diabetes Mellitus'. doi: 10.3889/MJMS.1857-5773.201.0.

Varol, E. et al. (2010) 'Mean platelet volume is associated with insulin resistance in non-obese, non-diabetic patients with coronary artery disease', Journal of Cardiology, pp. 154-158. doi: 10.1016/j. jjcc.2010.03.005.

Vivek, P. et al. (2018) 'Effects of different load on physiological, hematological, biochemical, cytokines indices of Zanskar ponies at high altitude', bioRxiv. doi: 10.1101/262253.

Worachartcheewan, A. et al. (2013) 'Machine learning approaches for discerning intercorrelation of hematological parameters and glucose level for identification of diabetes mellitus', EXCLI journal, 12, pp. 885-893. Available at: https://www.ncbi.nlm.nih. gov/pubmed/27092034. 